PeAKall, R. and P. E. SMouse (2006): GENALEX 6: genetic analysis in Excel. Population genetic software for teaching and research. Molecular Ecology Resources 6: 288-295.

Rajora, O. P., M. H. Rahman, S. Dayanandan and A. MosSELER (2001): Isolation, characterization, inheritance and linkage of microsatellite DNA markers in white spruce (Picea glauca) and their usefulness in other spruce species. Molecular and General Genetics 264: 871-882.
Selkoe, K. A. and R. J. Toonen (2006): Microsatellites for ecologists: a practical guide to using and evaluating microsatellite markers. Ecology Letters 9: 615-629.

Rousset, F. (2008): Genepop'007: a complete re-implementation of the GenePop software for Windows and Linux. Molecular Ecology Resources 8: 103-106.

VAllone, P. M. and J. M. Butler (2004): AutoDimer: a screening tool for primer-dimer and hairpin structures. Biotechniques 37: 226-231.

\title{
Investigating the Mendelian inheritance, genetic linkage, and genotypic disequilibrium for ten microsatellite loci of Araucaria angustifolia
}

\author{
By L. Medina-Macedo ${ }^{1)}$, A. E. B. Lacerda ${ }^{2), *)}$, J. Zanetti Ribeiro ${ }^{1)}$, J. V. M. Bittencourt ${ }^{3)}$ and A. M. SebBenN ${ }^{4)}$
}

(Received 16 $6^{\text {th }}$ March 2015)

\begin{abstract}
Araucaria angustifolia is a dioecious and wind pollinated conifer that typically occurs in higher attitudes of Southern Brazil. After a significant reduction of its population during the twentieth century, public policies have enabled natural populations to recover. As new studies focus on the genetics of the species it is important to investigate Mendelian inheritance, genetic linkage, and genotypic disequilibrium for the microsatellite loci developed for the species. Here we analyze ten microsatellite loci developed for $A$. angustifolia by genotyping 295 adult trees and 13 open pollinated progenies from a forest fragment in Santa Catarina, Brazil. The likelihood G-test shows a perfect 1:1 Mendelian segregation for all ten loci, indicating that these molecular markers are genetic markers. Significant genetic linkage between pairwise loci was detected in only $3 \%$ of the tests, suggesting that these loci are not located in the same linkage groups within the chromosomes. However, genotypic disequilibrium was detected in $51 \%$ of pairwise loci for adult trees, probably due to the strong spatial genetic structure of the population. Our results indicate that the ten loci analyzed can be used in studies on genetic diversity and structure, mating system, and gene flow of the species.
\end{abstract}

Key words: Araucaria; Conservation genetics; Microsatellites; pinheiro-do-paraná; Tropical tree species.

1) UFPR - Universidade Federal do Paraná, CP 19011, CEP 81531-990, Curitiba, PR, Brasil.

2) EMBRAPA Florestas, CP 319, CEP 83411-000, Colombo, PR, Brasil.

3) UTFPR - Universidade Técnica Federal do Paraná, CEP 84016-210, Ponta Grossa, PR, Brasil.

4) Instituto Florestal de São Paulo, CP 1322, CEP 01059-970, São Paulo, SP, Brasil.

*) For correspondence: ANDRE Eduardo Biscaia Lacerda. EMBRAPA Florestas, CP 319, Colombo, PR, Brasil, CEP 83411-000. E-Mail: andre.biscaia@embrapa.br

\section{Introduction}

With its unique crown shape and wide dispersion across Southern Brazil, the conifer Araucaria angustifolia is typical of the region's landscape. Its valuable timber was a focus of intensive logging during the twentieth century causing a dramatic reduction in its natural population. The species is currently classified as threatened with extinction on the Brazilian Red List (MARTINELLI and Moraes, 2013) and logging of the species is forbidden. Its protection has led to a gradual recovery in which new, natural populations are currently found across the region which has increased interest in the conservation of the species. Current methodologies, especially those using microsatellite markers (SSR), have been conducted for many tree species due to their high degree of polymorphism in terms of number of alleles (ASHLEY, 2010), which allow for a number of genetic analyses. Several current studies have examined existing populations of A. angustifolia for genetic variability, mating, and pollen flow; however, in order to validate the results obtained from the use of such molecular markers, it is essential to determine if the SSRs developed for the species have their loci linked and if their inheritance follows the Mendelian segregation assumptions.

Araucaria angustifolia (Bert.) O. Kuntze (Araucariaceae) - Brazilian pine - is a wind pollinated conifer, with seeds dispersed mainly by barochory (but with some zoochory by agoutis, birds, and squirrels). The species is mainly dioecious and it typically occurs at altitudes between 500 to $2300 \mathrm{~m}$ above sea level (asl). Because of its dominant position in the canopy, it is characteristic of the forest type, commonly known as Araucaria Forest (OMBRophylous MiXed ForEst; IBGE, 2012). The species presents pioneer-like behavior in abandoned areas and grasslands but it can also act as a 
Table 1. - Mendelian inheritance tests for ten microsatellite loci in progenies of Araucaria angustifolia.

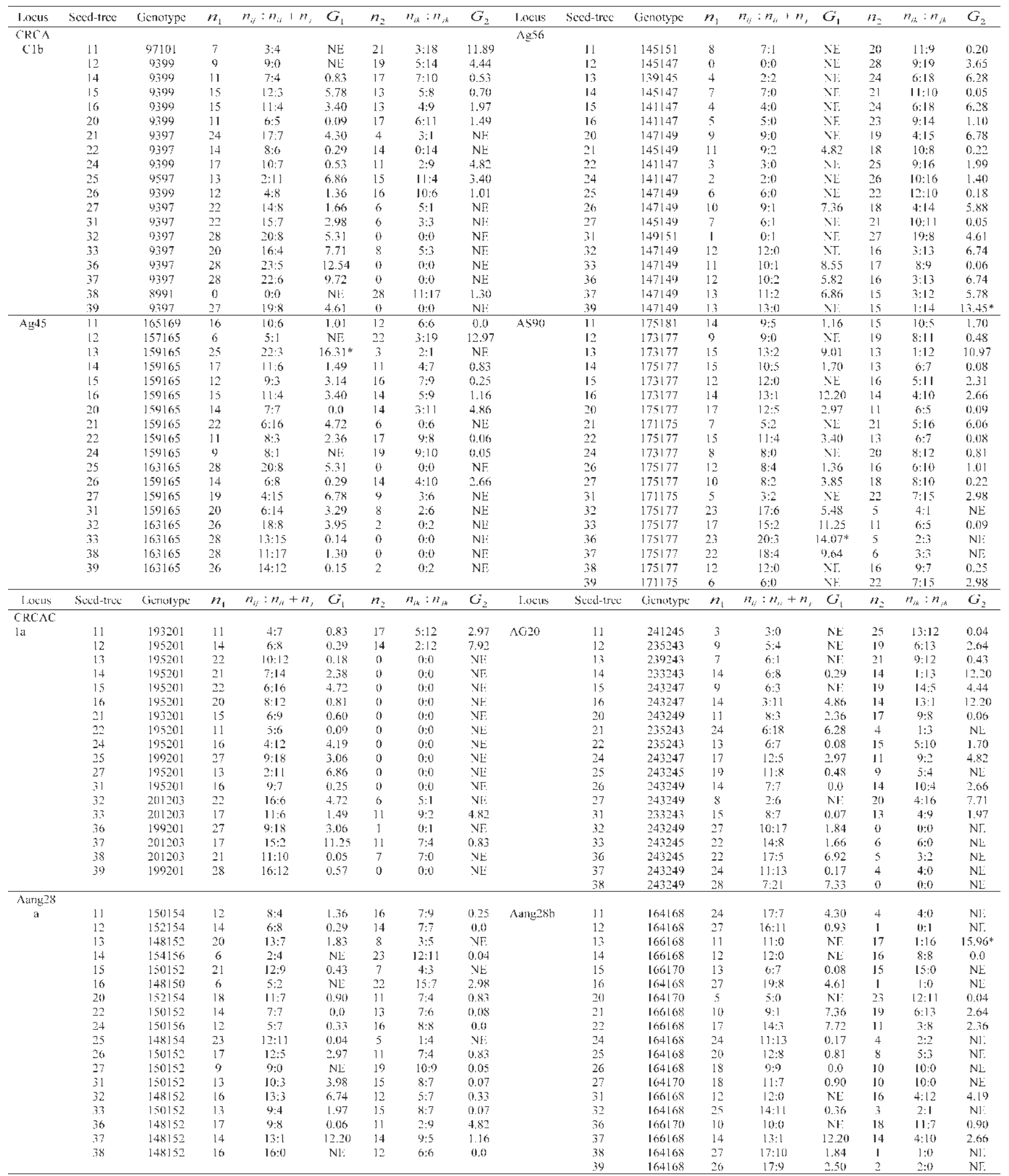

$n_{1}$ and $n_{2}=$ sample size; $G_{1}$ and $G_{2}=$ maximum likelihood G statistics for the hypothesis of $n_{i j}=n_{i i}+n_{j i}$ and $n_{i k}: n_{j k}$, respectively.

* Significance after Bonferroni correction for $\alpha=0.05\left(\chi^{2}=13.33\right)$. NE = not estimated for $n_{1}$ and $n_{2}$ was lower than 10 .

partially shade tolerant tree in forest environments. Because of its long life cycle, natural regeneration might be uncommon for long periods until gaps are formed in the forest canopy allowing for sapling development. On the other hand, the regeneration of the species is believed to be compromised by several factors such as dominance of invasive species in the understory (e.g., native bamboos), seed and seedling predation, and seed 
Continuation of Table 1.

\begin{tabular}{|c|c|c|c|c|c|c|c|c|c|c|c|c|c|c|c|c|c|}
\hline Lowus & Seed-tres & Genotype & $n_{1}$ & $n_{i j}: n_{j i}-n_{j}$ & $G_{1}$ & $n_{z}$ & $n_{i k}: n_{i k}$ & $G_{2}$ & Locus & Sced-tree & Genutype & $n_{1}$ & $n_{j, j}: n_{j i}+n_{j}$ & $G_{1}$ & $n_{2}$ & $n_{i k}: m_{i k}$ & $G_{2}$ \\
\hline \multirow[t]{18}{*}{ Mang01 } & 11 & 212218 & 3 & $3: 0$ & NH: & 25 & $11: 14$ & 0.36 & Aangl 4 & 11 & 205211 & 19 & $8: 11$ & 0.48 & 9 & $0: 9$ & YY. \\
\hline & 12 & 216222 & 1.3 & $9: 4$ & 1.97 & 1.5 & $3: 12$ & $5.7 \%$ & & 12 & 211217 & 21 & $11: 10$ & 0.05 & 6 & $2: 4$ & $x t$ \\
\hline & 13 & 218330 & 2 & I:I & $\mathrm{NE}$ & 26 & $9: 17$ & 2.50 & & 13 & 209211 & 22 & $8: 14$ & 1.66 & 6 & 0.6 & $\mathrm{NI}$ \\
\hline & 14 & 212216 & 11 & $9: 2$ & 4.82 & 17 & 9.8 & 0.06 & & 14 & 211213 & 19 & $12: 7$ & 1.33 & 9 & $4: 5$ & $\mathrm{IL}$ \\
\hline & 15 & 208216 & 12 & $8: 4$ & 1.36 & 16 & 9.7 & 0.25 & & 15 & 2017213 & 20 & $6: 14$ & 3.79 & 8 & $0: 8$ & Y]: \\
\hline & 16 & 210216 & 9 & $5: 4$ & NE & 19 & 8:11 & 0.48 & & 20 & 205219 & 0 & $0: 0$ & $\therefore E$ & 28 & $12: 16$ & 0.57 \\
\hline & 20 & 306213 & 21 & $9: 12$ & 0.43 & $?$ & 0.7 & $\mathrm{NE}$ & & 31 & 209211 & 12 & $8: 4$ & 1.36 & 16 & $9: 7$ & 0.25 \\
\hline & 22 & 214716 & 15 & $8: 7$ & 0.07 & 13 & $7: 6$ & 0,08 & & 24 & 211215 & 12 & $8: 4$ & 1.36 & 16 & $5: 11$ & 2.31 \\
\hline & 24 & 212222 & 7 & $4: 3$ & Nli: & 21 & $9: 12$ & 0.43 & & 26 & 211213 & 24 & $17: 7$ & 4.30 & 4 & $1: 3$ & S?]: \\
\hline & 2.5 & 208222 & 13 & $6: 7$ & 0.08 & 15 & $13: 2$ & 9.01 & & 37 & 21.3217 & 6 & $5: 1$ & X) & 22 & $14: 8$ & 1.66 \\
\hline & 26 & $21+216$ & 4 & 3:1 & $\mathrm{NE}$ & 24 & $11: 13$ & 0.17 & & 31 & 209211 & 9 & $6: 3$ & $X E$ & 19 & $8: 11$ & 0.48 \\
\hline & 27 & 2) 4216 & 2 & $2: 0$ & $N E$ & 26 & $10: 16$ & 1.40 & & 32 & 211215 & 15 & $8: 7$ & 0.07 & 13 & $5: 8$ & 0.70 \\
\hline & 32 & 212216 & 6 & 3,3 & NFE & 22 & $14: 8$ & 1.66 & & 3.3 & 211217 & 18 & $11: 7$ & 0.40 & 10 & 5.5 & (0.1) \\
\hline & 33 & 208212 & 11 & $5: 6$ & 0.09 & 17 & $8: 9$ & 0.069 & & 36 & 209217 & 5 & 32 & $\mathrm{NE}$ & 23 & $22: 1$ & $23.66^{*}$ \\
\hline & 36 & 300216 & 2 & $2: 10$ & NE & 26 & $13: 13$ & 0.0 & & 37 & 211217 & 15 & $9: 6$ & 0.60 & 1.3 & $9: 4$ & 1.97 \\
\hline & 37 & 208726 & 12 & 8:4 & 1.36 & 16 & $11: 5$ & 2.31 & & 38 & 211217 & 18 & $7: 11$ & 0.90 & 10 & $6: 4$ & 0.40 \\
\hline & 38 & 216226 & 3 & $3: 0$ & $\mathrm{NHE}$ & 25 & $15: 10$ & 1.01 & & 30 & 215217 & 6 & $4: 2$ & $\therefore L$ & 22 & 11:1! & 0.0 \\
\hline & 39 & 208214 & 16 & $9 \cdot 7$ & 0.25 & 12 & $2: 10$ & 5.82 & & & & & & & & & \\
\hline
\end{tabular}

$n_{1}$ and $n_{2}=$ sample size; $G_{1}$ and $G_{2}=$ maximum likelihood G statistics for the hypothesis of $n_{i j}=n_{i i}+n_{j j}$ and $n_{i k}: n_{j k}$, respectively.

* Significance after Bonferroni correction for $\alpha=0.05(\chi 2=13.33)$. NE = not estimated for $n_{1}$ and $n_{2}$ was lower than 10 .

collection for human consumption (e.g., LACERDA et al., 2012).

The reduction of continuous habitats into small forest fragments and problems with regeneration can cause an immediate decrease in genetic diversity due to the loss of alleles (WHITE et al., 1999). This is associated with a reduction in population size (CASCANTE et al., 2002), disruptions to natural mating systems, and interruptions to gene flow. In turn, these processes are linked to an increase in inbreeding levels and population divergence (Jump and Penuelas, 2006; Bittencourt and Sebbenn, 2007; SEBBEnN et al., 2011). In this context, the reduction of continuous $A$. angustifolia habitats into small forest fragments may interrupt gene flow and cause an immediate decrease in genetic diversity (BITTENCOURT and SebBenn, 2007; 2009). Thus, the genetic conservation of the species has become a priority that must be supported by studies of genetic diversity and structure as well as gene flow. Despite efforts to address areas of genetics analyses, such as pollen flow, mating systems, and effects of fragmentation on genetic variability, it is essential to confirm that basic assumptions regarding Mendelian inheritance, genetic linkage, and genotypic disequilibrium are met. As such, we aim to assess the Mendelian inheritance, genetic linkage, and genotypic disequilibrium for ten microsatellite loci developed for A. angustifolia.

\section{Materials and Methods}

The study was carried out in a 7 ha dense cluster of A. angustifolia inside the Embrapa Research Station in Caçador (ERSC), Santa Catarina State, Brazil. All 295 A. angustifolia trees in the study area had their vascular cambium sampled. We also sampled open-pollinated seeds from 13 randomly selected seed trees in the cluster and eight trees located in the adjacent open forest. From each seed tree, we genotyped 28 seeds from a single cone, with the exception of one tree located in the open forest, from which only 14 seeds were genotyped.

The isolation of DNA from A. angustifolia seeds followed the protocol described by MAZZA and BITTENCOURT (2000). The same protocol was applied to the vascular cambium tissue from adult trees with minor modifications (removal of proteinase $\mathrm{K}$ and CTAB $10 \%(\mathrm{NaCl} 1.4$ M) solutions). Quantification was performed comparing $5 \mu \mathrm{L}$ of the DNA from each sample with $5 \mu \mathrm{L}$ of Phage Lambda DNA size marker with concentrations of 20, 50 and $100 \mathrm{ng}$ in $2 \%$ agarose gel. After quantification, each sample was diluted with autoclaved Milli-Q water to a final concentration of $10 \mathrm{ng} / \mu \mathrm{L}$ to begin tests with SSR markers. Of the 20 pairs of microsatellite markers available for A. angustifolia, eight were selected to be amplified in three multiplex systems.

The PCR reactions were performed using the Qiagen Multiplex PCR Master Mix in a final volume of $10 \mu \mathrm{L}$, containing $5 \mu \mathrm{L}$ of PCR Master Mix (2x), $1 \mu \mathrm{L}$ of primer pairs ( $2 \mathrm{mM}$ each primer), $2 \mu \mathrm{L}$ of genomic DNA $(10 \mathrm{ng} / \mathrm{\mu L})$, and $1 \mu \mathrm{L}$ of $\mathrm{Q}$-Solution and Milli-Q water. The PCR program used in the thermocycler involved: (1) an initial step at $95^{\circ} \mathrm{C}$ for 15 min for DNA denaturation and Taq DNA polymerase activation; (2) 35 cycles of amplification in three stages $\left(94^{\circ} \mathrm{C}\right.$ for $30 \mathrm{~s}$, annealing temperature for $90 \mathrm{~s}$, and extension at $72^{\circ} \mathrm{C}$ for $60 \mathrm{~s}$ ); and (3) a final extension at $72^{\circ} \mathrm{C}$ for $10 \mathrm{~min}$. After amplification, $10 \mu \mathrm{L}$ of Milli-Q water was added to each sample which were then refrigerated at $4{ }^{\circ} \mathrm{C}$ until genotyping. For genotyping, we used a solution of $10 \mu \mathrm{L}$ containing $2 \mu \mathrm{L}$ of the amplified fragment solution from each sample, $0.125 \mu \mathrm{L}$ of sequencer standard ROX GS 500 or LIZ GS 600, and the remaining volume with HiDi formamide. Polymorphism was detected by labeling SSR primer pairs marked with fluorescent dyes in triplex or duplex combinations, followed by capillary electrophoresis to detect fragments in a 3500xL ABI Genetic Analyzer automated sequencer (Applied Biosystems). The size of amplified fragments (alleles) were determined using the GeneMapper v.4.1 software (Applied Biosystems) and the values referring to the size of the alleles were exported to a spreadsheet for statistical analyses.

The method described by GILLET and HatTEMER (1989) was used to investigate the Mendelian inheritance of the A. angustifolia SSR loci, which is based on comparisons of a heterozygous maternal genotype tree with the segregation of its alleles in open-pollinated progeny. 
Table 2. - Maximum likelihood G-test for the hypothesis of independent segregation between pairwise loci (1:1:1:1) in progenies of Araucaria angustifolia. ST is the seed tree.

\begin{tabular}{|c|c|c|c|c|c|c|c|c|c|c|c|c|c|c|c|c|c|}
\hline \multirow{3}{*}{ ST } & \multicolumn{9}{|c|}{ CRCAClb } & \multicolumn{8}{|c|}{$A(556$} \\
\hline & \multicolumn{5}{|c|}{ CRCAC } & \multirow{2}{*}{$\begin{array}{c}\text { Aang28 } \\
\text { a }\end{array}$} & \multirow{2}{*}{$\begin{array}{c}\text { Aang } 28 \\
b\end{array}$} & \multirow[b]{2}{*}{ A:mingol } & \multirow[b]{2}{*}{$A_{\operatorname{arl}} \leq \mathrm{s} \mid 4$} & \multirow[b]{2}{*}{$\mathrm{AC}, \overline{9}$} & \multirow[b]{2}{*}{ As9o } & \multicolumn{2}{|l|}{$\mathrm{C} R \mathrm{RCA}$} & \multicolumn{4}{|l|}{ Aang? 28} \\
\hline & $\operatorname{Ang} 59$ & $A(\mathrm{i} 4,5$ & As90 & $1 a$ & $A G 20$ & & & & & & & 6 & $\Lambda G i 20$ & it & A4nug $28 b$ & Aamlg! 1 & A $\sin 1514$ \\
\hline 11 & 7.79 & 4.10 & 10.07 & 9.90 & 2.58 & 1.46 & 5.28 & 15.81 & 23.26 & 1.63 & 5.12 & 6.63 & 2.86 & 3.61 & 1.42 & 6.54 & 13.31 \\
\hline 12 & 7.66 & 13.33 & 2.80 & 16.43 & 9.73 & 1.33 & 4.47 & 10.30 & 9.91 & 6.70 & 2.08 & 0.88 & 4.91 & 2.14 & 1.75 & $5.6 \%$ & 3.43 \\
\hline 13 & NF & RiF. & 0.67 & 4.81 & $\triangle F$ & 0.73 & 4.50 & $N E$ & $R F$ & 9.93 & 8.09 & 8.84 & 11.42 & 17.48 & 7.29 & 1.51 & 30.56 \\
\hline 14 & 2.07 & 10.09 & 0.13 & $26.53^{+4}$ & 22.76 & 2.44 & 1.37 & 0.20 & 0.79 & 1.87 & 0.38 & 7.10 & 17.92 & 2.97 & 3.80 & 0.90 & 3.92 \\
\hline 15 & 4.65 & 5.00 & 1.13 & 8.90 & 4.04 & 0.72 & 11.00 & 1.69 & 16.17 & 13.37 & 6.96 & 12.31 & 6.07 & 8.99 & 11.91 & 8.64 & VIL: \\
\hline 16 & 7.31 & 16.46 & 0.59 & 13.31 & 18.20 & 3.25 & 0.38 & 9.52 & $N E$ & 3.15 & 2.10 & 9.02 & 12.90 & 5.56 & 2.42 & 1.82 & NF \\
\hline 21 & 3.54 & 16.50 & 4.54 & 7.22 & 21.69 & Vl: & 5.35 & Niti & 0.47 & 0.21 & 6.20 & 6.49 & 16.78 & vili & 6.52 & Nit & 1.77 \\
\hline 22 & 5.42 & 11.14 & 8.96 & 26.19 & 16.61 & 9.23 & 10.37 & 10.96 & $\mathrm{NE}$ & 1.62 & 5.24 & $15,4 \overline{5}$ & 3.02 & 3.88 & 2.92 & 4.49 & VI: \\
\hline 24 & 12.30 & 7.18 & 1.85 & 11.02 & 2.42 & 7.48 & 0.90 & 0.06 & 5.011 & 6.94 & 4.09 & 11.09 & 2.36 & 15.30 & 8.55 & 4.6 .3 & 3.36 \\
\hline 25 & 18.82 & 8.29 & 10.90 & 15.67 & $24,52^{*}$ & $23.60^{*}$ & 1.87 & 10.34 & KE: & 2.20 & 1.92 & 1,90 & 1.81 & 13.73 & 1.51 & 12,67 & NT: \\
\hline 26 & 9.57 & 7.57 & 1.52 & $\mathrm{Nl}$ & 7.00 & 1.14 & 2.15 & 2.77 & 1.18 & 10.06 & 5.00 & NH: & 8.21 & 2.40 & 3.90 & 0.24 & 0.50 \\
\hline 27 & 5.96 & 20.83 & 0.32 & 10.40 & 4,87 & 0.29 & 7.00 & 5.00 & 10.48 & 11.55 & 0.05 & 7.99 & 2.00 & 0.63 & 16.90 & 0.78 & 7.24 \\
\hline 31 & 5.42 & 8.29 & 5.12 & 4.69 & 9.96 & 1.70 & 1.69 & $M E$ & 2.02 & 6.78 & 1.62 & 5.65 & 5.86 & 4.11 & 6.74 & $\mathrm{NE}$ & 1.36 \\
\hline 32 & 4.93 & 2.10 & 3.10 & 1.88 & 7.98 & 3.29 & 9.03 & 7.39 & 3.35 & 1.20 & 2.39 & 2.91 & 17.24 & 603 & 1.59 & 9.95 & 3.12 \\
\hline 36 & 6.28 & 3.17 & 0.76 & 16.94 & 0.95 & 7.57 & 8.50 & 0.72 & $26.31^{*}$ & 0.90 & 1.67 & 3.91 & 1.21 & 9.87 & 0.44 & 2.81 & 22.48 \\
\hline 37 & 2.49 & 6.98 & 1.92 & 3.39 & 20.34 & 3.87 & 2.81 & 6. .55 & 5.62 & 1.75 & 1.81 & 1.6 .3 & 19.46 & 1.21 & 0.03 & 8.90 & 2.84 \\
\hline 38 & 1.88 & 18.59 & 11.81 & 3.47 & 3.36 & 6.12 & 6.14 & 4.18 & 1.48 & 1.61 & 1.11 & 11.27 & 30.20 & 3.08 & 2.09 & 2.35 & 2.33 \\
\hline 39 & 2.91 & 4.64 & 7.58 & 6.89 & Xil: & vr: & 3.14 & 3.73 & 1.30 & 7.67 & 3.36 & 10.64 & $\mathrm{Mr}$ & $.11:$ & 1.83 & 2.57 & 0.96 \\
\hline
\end{tabular}

\begin{tabular}{|c|c|c|c|c|c|c|c|c|c|c|c|c|c|}
\hline \multirow{3}{*}{ SI } & \multicolumn{7}{|c|}{$\mathrm{AG} 45$} & \multicolumn{6}{|c|}{ AS90 } \\
\hline & \multicolumn{3}{|c|}{ CRGA } & \multirow{2}{*}{$\begin{array}{c}\operatorname{Aang} 28 \\
a \\
\end{array}$} & \multirow[b]{2}{*}{$\operatorname{Aang} 28 \mathrm{~b}$} & \multirow[b]{2}{*}{ Aangol } & \multirow[b]{2}{*}{ Aang14 } & \multirow{2}{*}{$\begin{array}{c}\text { CRGAC } \\
\text { la }\end{array}$} & \multirow[b]{2}{*}{$\mathrm{A} C \mathrm{j} 20$} & \multirow{2}{*}{$\begin{array}{c}\operatorname{Mang} 28 \\
a\end{array}$} & \multirow[b]{2}{*}{ Aang $28 \mathrm{~b}$} & \multirow[b]{2}{*}{ Aang $0 !$} & \multirow[b]{2}{*}{ Aangl 4} \\
\hline & $A 590$ & Cla & $\mathrm{AO}_{20}$ & & & & & & & & & & \\
\hline [.] & 1.74 & 9.05 & 4.21 & 2.87 & 6.18 & 1.97 & 8.95 & 8.27 & 1.12 & 2.69 & 1.17 & 1.3 .57 & 19.6 .3 \\
\hline 12 & 12.95 & 9.92 & 10.22 & 2.37 & 9.88 & 4,53 & 19.22 & 6.61 & 7.14 & 6.44 & 6.78 & 4.63 & 5.65 \\
\hline 1.3 & 5,55 & 5.64 & 0.81 & 2,10 & 10,71 & 1.52 & 21.85 & 8.64 & 9), (12) & 10,90 & 7.85 & 2.97 & 18.97 \\
\hline 14 & 2.95 & 5.64 & 19.04 & 0.50 & 2.21 & 1.35 & 0.55 & 12.30 & 18.01 & 2.70 & 5.88 & 2.02 & 2.66 \\
\hline 15 & 2.3 .3 & 6.32 & 6.82 & ].3 L & 10.80 & 0.30 & 11.12 & 7.69 & 8.38 & 1.33 & 10.69 & 2.3 .3 & 11.65 \\
\hline 16 & 2.18 & 6.35 & 16.14 & 3.01 & 1.22 & 3.02 & NF & 7.77 & 12.18 & 3.95 & 1.59 & 0.51 & $\mathrm{NF}$ \\
\hline 20 & $11 . .31$ & v]: & 8.91 & 7.58 & 13.54 & 14.05 & 11.90 & VI: & 302 & 4.15 & 9.41 & $8 .(0)$ & 0.83 \\
\hline 21 & 18.06 & $27.13^{\circ}$ & $30.25^{\circ}$ & $\mathrm{VL}$ & 22.77 & RE & 17.37 & 11,04 & $23.74 *$ & $\mathrm{NE}$ & 15.27 & $\mathrm{NE}$ & 9.51 \\
\hline 22 & 2.61 & 15.69 & 4.51 & 0.96 & 1.58 & 1.82 & vr: & 7.95 & 3.61 & 3.92 & 0.70 & 4.11 & $\mathrm{NE}$ \\
\hline 24 & 0.58 & 4.45 & 4.12 & 0.03 & 3.60 & 0.38 & 1.75 & 3.00 & 15.50 & 0.47 & 7.59 & 0.68 & 4.20 \\
\hline 25 & 1.40 & 11.04 & 4.27 & 7.13 & 4.53 & 9.71 & VI: & 16.76 & 3.75 & 6,60 & 4.37 & 7.98 & vli \\
\hline 26 & 10.18 & vis: & 12.08 & 10.98 & 10.32 & 3.1 .3 & 9.71 & $. \mathrm{VI}:$ & 4.1 .5 & 2.52 & .3 .0 .3 & 4.16 & 3.55 \\
\hline 27 & 8.86 & $25.04 *$ & 10.92 & $25.35^{*}$ & 16.15 & 8.15 & 15.46 & 9.95 & 1.56 & 0.91 & 8.68 & 2.99 & 2.15 \\
\hline 31 & 22,92 & 18.37 & 22.78 & 13.62 & 14,78 & Ni: & 17.61 & 6.07 & 12,04 & 4,95 & 8.82 & NI: & 13.20 \\
\hline 32 & 4.92 & 3.22 & 18.68 & 2.80 & 6.86 & 5.05 & 1.53 & 10.65 & 17.65 & 1.73 & 3.03 & 4.79 & 1.77 \\
\hline 3.3 & 3.69 & 7.96 & $31.36^{\circ}$ & 5.00 & 1.48 & 3.69 & 7.27 & 4.63 & 16.02 & 1.21 & 0.014 & 0.46 & 1.23 \\
\hline 36 & 4.15 & 14.18 & 4.92 & 4.05 & 1.47 & 3.25 & 29.41 & 15.95 & 1.11 & 8.46 & 3.79 & $0.6 \overline{5}$ & 22.55 \\
\hline 37 & 2.06 & 0.8 .3 & $27.53^{*}$ & 3.82 & 0.65 & 7.27 & 8.40 & 2.88 & $\mathrm{Nil}$ & 0.50 & 0.53 & 6.6 .3 & 7.30 \\
\hline 38 & 1.43 & 11.00 & $3009^{*}$ & 1.48 & 0.92 & 2.15 & 3.46 & 0.13 & 583 & 0.31 & 1.38 & 2.46 & 0.52 \\
\hline 39 & 6.87 & 15.15 & Nit: & VIl: & 5.01 & 5.55 & 2.80 & $8.5 \overline{5}$ & Mit: & $\mathrm{NH}$ & 8.07 & 8.80 & 1.36 \\
\hline
\end{tabular}

\begin{tabular}{|c|c|c|c|c|c|c|c|c|c|c|c|c|c|c|c|}
\hline \multirow[b]{2}{*}{ S1 } & \multicolumn{5}{|c|}{ CKCACIa } & \multicolumn{4}{|c|}{$\Lambda G 20$} & \multicolumn{3}{|c|}{ Aang28a } & \multicolumn{2}{|c|}{ Aang 28 r } & \multirow{2}{*}{$\frac{\text { Aangl } 1}{\text { Aangl } 4}$} \\
\hline & $\mathrm{Ar} 20$ & $\begin{array}{c}\operatorname{Aang} 28 \\
\mathrm{a}\end{array}$ & Aangesb & Aangol & Aang14 & $\begin{array}{c}\operatorname{Aang} 28 \\
a\end{array}$ & Aang $28 b$ & Aang 01 & Aang 14 & Aang28a & Aanng0 1 & Aangl 4 & Aang 01 & Anng 4 & \\
\hline 11 & 7.65 & 13,00 & 14.22 & 4.09 & KL & 5.97 & 7.31 & 2.40 & 11.63 & 10.81 & 1.77 & $23.63 *$ & 0.55 & 24.02 & 11.50 \\
\hline 12 & 22.43 & 4.63 & 9.61 & 18.07 & 14.75 & 3.77 & 7.69 & 6.70 & 9.17 & 5.17 & 4.97 & 3.80 & 10.77 & 11.84 & 9.34 \\
\hline 13 & 3.95 & 14.47 & 10.03 & 1.30 & 18.78 & 0.27 & 5.28 & 0.88 & 16.89 & 7.12 & 3.46 & 16.53 & 5.09 & 1,92 & 8.60 \\
\hline 14 & $2600^{*}$ & 1.55 & 801 & 2.16 & 5.01 & 17.37 & $26.56 \%$ & 14.80 & 16.30 & 2.91 & 1.60 & 4.75 & 1.25 & 0.28 & 4.57 \\
\hline 15 & 8.98 & 11.61 & 11.012 & 7.53 & 20.06 & 6.48 & 17.10 & 3.72 & 8.70 & 16.91 & 0.21 & $23.47 *$ & 6.55 & 13.72 & $|1.3|$ \\
\hline 16 & $11.5 \%$ & $10.0 \mathrm{~g}$ & 7.85 & 3.87 & KF & 4.25 & $20.0 x$ & 8.65 & $28.91 *$ & 4.25 & 3.30 & NE & 1.35 & NF. & $R E$ \\
\hline 20 & $N E$ & $\mathrm{NF}$ & $N F$ & $N=$ & NT: & 5.82 & 7.80 & 8.75 & 10.75 & 5.00 & 9.93 & 1.18 & 14.42 & 3.71 & 17.44 \\
\hline 21 & $25.27^{*}$ & VE: & 13.85 & NEL & 11.31 & YVL & 20.14 & 8.75 & $N E$ & $\mathrm{VL}$ & NE: & NE: & $N E:$ & 1.28 & Nil: \\
\hline 22 & 19.48 & 6.68 & 6.03 & 8.57 & KL & 4.60 & 3.38 & 3.17 & 6.30 & 1.64 & 3.03 & $\mathrm{NE}$ & 0.58 & $\mathrm{NL}$ & $\mathrm{NL}$ \\
\hline 24 & 5.59 & 7.35 & 11.30 & 3.28 & 5.64 & 9.41 & 8.61 & 3.52 & $N E$ & 2.82 & 3.88 & 2.44 & 1.75 & 3.75 & 1.12 \\
\hline 25 & 6.62 & 1.3 .22 & 14.56 & 16.23 & ki. & 10.39 & 1.41 & 6.85 & 4.86 & 4.45 & NE: & NE: & 11.79 & $\mathrm{NT}$ & $N \Gamma$ \\
\hline 26 & Nis: & $V \mathrm{VL}$ & $\mathrm{ML}$ & $N L$ & $\mathrm{NL}$ & 6.03 & 3.86 & 8.22 & 9.46 & 0.83 & 2.43 & 4.07 & 0.53 & 5.94 & 5.93 \\
\hline 27 & 21.85 & 7.89 & 18.27 & 2.30 & 11.37 & 7.80 & 11.04 & 0.90 & 11.38 & 3.65 & 0.36 & 1.21 & 5.70 & 18.17 & 4.60 \\
\hline 31 & 10.07 & 1.26 & 2.37 & NE: & 2.47 & $6.7 x$ & 10.97 & VI: & 8.38 & 0.38 & NE: & 5.17 & NEF & 2.40 & $A E$ \\
\hline 32 & 17.31 & 1.37 & 4.89 & 4.96 & 0.52 & 7.59 & 8.65 & 8.53 & 21.41 & 9.74 & 11.59 & 2.14 & 4.82 & 3.22 & 7.59 \\
\hline 3 & $33.67 *$ & 5.01 & 4.77 & 6.38 & 7.21 & 17.65 & $28.24 \%$ & 20.99 & $34.37 *$ & 0.29 & 0.97 & 8.80 & 683 & 5.05 & 3.35 \\
\hline 36 & 9.37 & $28.63 *$ & 2.19 & 12.04 & $\mathrm{NL}$ & 12.34 & 2.31 & 2.52 & 17.69 & 12.99 & 1.73 & 14.16 & 1.53 & 20.19 & 5.71 \\
\hline 37 & $28.52^{*}$ & 0.11 & 1.89 & 5.84 & 5.16 & 30.42 & $28.12^{\circ}$ & 15.82 & 18.89 & 7.25 & 9.92 & 1.19 & 7.36 & 4.87 & 8.19 \\
\hline 38 & $N F$ & 5.61 & 6.15 & 10.11 & 6.78 & 18.15 & 12.62 & 10.09 & $N E$ & 2.29 & 2.95 & 2.65 & 3.02 & 1.40 & 4.80 \\
\hline 39 & Ni: & $\mathrm{VI}$ & 15.63 & 8.55 & 2.03 & VI: & VI: & $\mathrm{NI}:$ & NE: & VI: & Nr: & Nl: & 3.15 & 0.50 & 4.4 .3 \\
\hline
\end{tabular}

* Significance after Bonferroni correction for $\alpha=0.05$. $0.00029(\chi 2=23.28) . \mathrm{G}=\mathrm{G}$-test for three degrees of freedom. NE $=$ not estimated. 
This method assumes that the loci have regular segregation and its alleles follow classic Mendelian inheritance patterns based on three main requirements: 1) regular meiotic segregation during ovule production; 2) random ovule fertilization by type of pollen; 3) no selection occurring between the moment of fertilization and genotyping of the seeds. The model also assumes that there is a co-dominant relationship among all alleles. The method further requires that the following conditions are met: 1) all progeny of a tree must possess a maternal allele; and 2) in cases of heterozygous parent trees (e.g. $A_{i} A_{j}, \mathrm{i} \neq \mathrm{j}$ ): a) each offspring must possess an allele of the maternal tree, $A_{i}$ or $A_{j}$; b) the number of heterozygous progeny $A_{i} A_{j}\left(n_{i j}\right)$ must be equal to the sum of homozygous progeny $A_{i} A_{i}\left(n_{i i}\right)$ and $A_{j} A_{j}\left(n_{j j}\right)$, or $n_{i j}=n_{i i}+$ $n_{i j}$; and c) the number of heterozygous progeny $A_{i} A_{k}\left(n_{i k}\right)$ must equal the number of heterozygous progeny $A_{j} A_{k}$ $\left(n_{i k}\right)$, or $n_{i k}=n_{j k}$, where $\mathrm{k} \neq \mathrm{i}, \mathrm{j}$. Based on this model, and using the open-pollinated progenies sampled from 25 seed-trees during two reproductive events, we compared the segregation observed in each progeny of the heterozygous maternal tree for a given loci with the expected hypothesis of regular Mendelian 1:1 segregation, the G-test (SOKAL and ROHLF, 1981), based on the following formula (Equation 1):

$$
G=2\left[n_{i j} \ln \left(\frac{n_{i j}}{E(n)}\right)+\left(n_{i i}+n_{i j}\right) \ln \left(\frac{\left(n_{i i}+n_{j j}\right)}{E(n)}\right)\right]
$$

(Equation 1)

where $l n$ is the natural logarithm, and $E(n)$ is the expected number of genotypes for the alleles $A_{i} A_{j}\left(n_{i j}\right)$ and $A_{i} A_{i}+A_{j} A_{j}\left(n_{i i}+n_{j j}\right)$, based on: $E(n)=0.5\left(n_{i j}+n_{i i}+\right.$ $n_{j j}$ ) or based on Equation 2:

$$
G=2\left[n_{i k} \ln \left(\frac{n_{i k}}{E(n)}\right)+n_{j k} \ln \left(\frac{n_{j k}}{E(n)}\right)\right]
$$

(Equation 2)

where, $E(n)$ is the expected number of genotypes for the alleles $A_{i} A_{k}\left(n_{i k}\right)$ and $A_{j} A_{k}\left(n_{j k}\right)$, based on: $E(n)=$ $0.5\left(n_{i k}+n_{j k}\right)$. Additionally, a Bonferroni correction for multiple comparisons $(95 \%, \alpha=0.05)$ was used to avoid false positives.

To test whether the loci of progeny were genetically linked, a linkage test was carried out between pairwise loci, using genetic information from parent trees that were doubly-heterozygous for two loci. In this case, the null hypothesis $\left(H_{0}\right)$ is the regular Mendelian 1:1:1:1 segregation. The hypothesis of regular segregation between pairwise loci was accepted or discarded based on a maximum likelihood G-test (SOKAL and ROHLF, 1981), shown in Equation 3, performed for each progeny:

$$
\begin{aligned}
G= & 2\left[n_{i k} \ln \left(\frac{n_{i k}}{E(n)}\right)+n_{i l} \ln \left(\frac{n_{i l}}{E(n)}\right)+\right. \\
& \left.n_{j k} \ln \left(\frac{n_{j k}}{E(n)}\right)+n_{j l} \ln \left(\frac{n_{j l}}{E(n)}\right)\right]
\end{aligned}
$$

(Equation 3)

where, $n_{i k}, n_{i l}, n_{j k}$, and $n_{i l}$ are the observed number of phenotypes $A_{i} B_{k}, A_{i} B_{l}, A_{j} B_{k}$, and $A_{j} B_{l}$, respectively; $E(n)$ is the expected number of genotypes $A_{i} B_{k}, A_{i} B_{l}$, $A_{j} B_{k}$, and $A_{j} B_{l}$, respectively; is the natural logarithm; and $E(n)$ is calculated as $E(n)=0.25\left(n_{i k}+n_{i l}+n_{j k}+n_{i l}\right)$. The Bonferroni correction for multiple comparisons $(95 \%, \alpha=0.05)$ was also applied.
The genotypic disequilibrium test was carried out for adult trees, since genotypic disequilibrium is expected in progeny arrays because descendants always receive a maternal allele. The genotypic disequilibrium test was carried out using the FSTAT program (GouDET, 2002) associated with a Bonferroni correction $(95 \%, \alpha=0.05)$.

\section{Results}

After the Bonferroni correction, significant deviations from the expected 1:1 Mendelian segregation pattern were detected in only five (2\%) of 251 tests (Table 1). After the Bonferroni correction, 25 of the 807 linkage tests $(3 \%)$ were significant (Table 2$)$, suggesting absence of linkage between pairwise loci. However, the genotypic

\begin{tabular}{|c|c|}
\hline Pairwise loci & Adult trees \\
\hline CRCAClbXAG56 & 0.00016 \\
\hline CRCACIbXAG45 & 0.00016 \\
\hline CRCACIBXAS9O & $0.0001 \mathrm{G}$ \\
\hline CRCAClbXCRCACla & 0.00016 \\
\hline CRCAC1bXAG20 & 0.00016 \\
\hline CRCAC:IhXAanglRa & 0.00016 \\
\hline CRCAC:1bXAang $28 \mathrm{~b}$ & 0.04429 \\
\hline CRCACIbXAangol & 0.00016 \\
\hline CRCAC 1 bXAang 14 & 0.00159 \\
\hline AG56XAG45 & 0.00016 \\
\hline$\triangle G 56 \times \wedge S 90$ & 0.00016 \\
\hline AG56XCRCACla & 0.00016 \\
\hline$A G 56 \times A G 20$ & 0.00016 \\
\hline AG56X 5 ang 28 a & 0.02254 \\
\hline AC5 $56 \times$ Aang $28 \mathrm{~h}$ & 0.67206 \\
\hline A(356XAmgol & 0.00302 \\
\hline AG56XAang 14 & 0.15635 \\
\hline AG45XAS90 & 0.00016 \\
\hline AG45XCRCACla & 0.00016 \\
\hline$\Lambda G 45 \times \Lambda G \geq 0$ & 0.00016 \\
\hline AG45XAang28: & 0.03079 \\
\hline NG45X $\wedge$ ang $28 \mathrm{~h}$ & 0.01016 \\
\hline AG45XAang 01 & 0.05794 \\
\hline $\mathrm{AG} 45 \mathrm{X}$ A ang 14 & 0.00810 \\
\hline As $90 \times C R C A C l d$ & 0.00016 \\
\hline$\triangle 590 \times \wedge C 20$ & 0.00016 \\
\hline A590XAang28a & 0.01413 \\
\hline AS90X Aang $28 \mathrm{~b}$ & 0.21429 \\
\hline As90XAang0l & 0.00381 \\
\hline AS90XAang 14 & 0.07460 \\
\hline CRCACIaXAG & 0.00016 \\
\hline CRCAClaXAang $28 a$ & 0.36746 \\
\hline CRCAClaXAang28b & 0.55587 \\
\hline (RCAClaXAang01 & 0.14746 \\
\hline CRCAClaXAangl4 & 0.07381 \\
\hline AG20XAang28a & 0.04492 \\
\hline NG20XAang28b & 0.00016 \\
\hline A(j20XAang 01 & 0.00016 \\
\hline AG20XAang 14 & 0.02492 \\
\hline Aang 28 a X A ang $28 \mathrm{~b}$ & 0.00016 \\
\hline Aang 28 a $X$ Aang 1 & 0.00016 \\
\hline Aang28aX Aang 14 & 0.04460 \\
\hline Acung $28 \mathrm{~b} \times$ Aungo 1 & 0.00016 \\
\hline Aang $28 \mathrm{~b} X$ Aang 14 & 0.02889 \\
\hline Aang01 X Aang14 & 0.00016 \\
\hline
\end{tabular}

Table 3. - Results for the genotypic disequilibrium analysis between pairwise microsatellite loci from adult trees of Araucaria angustifolia.

The values represent the probability of genotypic disequilibrium after 1200 permutations of alleles among individuals. Probability after Bonferroni correction: $\mathrm{P}=0.00016 ; \alpha=0.05$. 
disequilibrium was detected in $51 \%$ of pairwise loci for adult trees (Table 3), probably due to the presence of strong spatial genetic structure of the population.

\section{Discussion}

The results showed that the ten microsatellite loci segregated according to the Mendelian rules of $1: 1$. In general, the five cases where deviations were detected occurred at different loci in the same progenies, suggesting that the observed deviations can be attributed to sample drift, considering that $A$. angustifolia cones contain many seeds ( $>200$ ) and the maximum sample size was 28 seeds per tree. Furthermore, the deviation occurred in only one of the realized tests $\left(n_{i j}: n_{i i}+n_{i j}\right.$ or $\left.n_{i k}: n_{j k}\right)$, indicating that these deviations are random and these loci segregate according to Mendelian rules. Thus, the ten microsatellite markers can be considered genetic markers. Similarly, Mendelian segregation for the loci Ag45, AS90, CRCAC1a, Ag20, Aang28a, Aang01 and Aang14 was previously validated by DANNER et al. (2013).

Linkage between some pairs of loci was detected for a limited number of tests. The significant linkage between pairwise loci for some progenies came from individual locus deviations from the 1:1 Mendelian segregation because progenies with Mendelian deviations in some loci were used for the linkage tests. For example, the progeny of seed tree 36 showed deviations from the 1:1 Mendelian segregation for locus Aang14 and linkage with CRCAC1b, indicating that the segregation deviations in an individual locus may have generated the significant G-test values. Thus, all loci can be used for population genetic analyses such as genetic diversity and structure, mating system, and gene flow.

Evidence of genotypic disequilibrium between pairs of loci in adult trees was detected in $51 \%$ of the tests, suggesting high linkage disequilibrium. The genotypic disequilibrium is typical of a population and is caused by many factors including small sample size, selfing, mating among relatives, correlated mating, bottlenecks and founder effects, artificial and natural selection, and intrapopulation spatial genetic structure. Because the size of our sample population is high (295) and the tree species is dioecious and long-living (no selfing occurs), we believe that intrapopulation spatial genetic structure was the cause of the observed genotypic disequilibrium between many pairs of loci.

As a conclusion, the ten loci assessed herein present Mendelian inheritance and are not linked. Thus, these loci can be used in population genetic analyses, especially in mating system and parentage analysis studies.

\section{Acknowledgments}

We would like to acknowledge the Brazilian Agriculture Research Corporation (EMBRAPA) for logistics and financial support and the Federal University of Paraná (UFPR) and Technical Federal University of Paraná (UTFPR) for infrastructure made available for this study. Finally, we thank Dr. EvELYN NimMo for her editing of the manuscript.

\section{References}

Ashley, M.V. (2010): Plant parentage, pollination, and dispersal: how DNA microsatellites have altered the landscape. Critical Reviews in Plant Sciences 29(3): 148-161.

Bittencourt, J. V. M. and A. M. Sebbenn (2007): Patterns of pollen and seeds dispersal in a small, fragmented population of the wind pollinated tree Araucaria angustifolia in southern Brazil. Heredity 99: 580-591.

BitTencourt, J. V. M. and A. M. SebBenn (2009): Genetic effects of forest fragmentation in high-density Araucaria angustifolia populations in Southern Brazil. Tree Genet Gen: 573-582.

Cascante, A., M. Quesada, J. J. Lobo and E. A. Fuchs (2002): Effects of dry tropical forest fragmentation on the reproductive success and genetic structure of the tree Samanea saman. Conserv Biol 16: 137-147. doi:10.1046/j.1523-1739.2002.00317.x

Danner, M. A., J. Z. Ribeiro, F. Zanette, J. V. M. BittenCOURT and A. M. SEBbenN (2013): Mendelian segregation in eight microsatellite loci from hand- and openpollinated progenies of Araucaria angustifolia (Bert.) O. Kuntze (Araucariaceae). Silvae Genet. 62: 18-25.

Gillet, E. and H. H. HATTEMER (1989): Genetic analysis of isoenzyme phenotypes using single tree progenies. Heredity 63: 135-141.

GOUDET, J. (2002): FSTAT (Version 2.9.3.2.): a computer program to calculate F-statistics. J. Hered. 86: 485-486.

IBGE (2012): Manual Técnico da Vegetação Brasileira, $2^{\text {nd }}$ edition ed. IBGE, Rio de Janeiro.

Jump, A. S. and J. Penuelas (2006): Genetic effects of chronic habitat fragmentation in a wind-pollinated tree. PNAS - Proc Natl Acad Sci 103: 8096-8100. doi:10.1073/pnas.0510127103

Lacerda, A. E. B., M. A. D. Rosot, A. F. Filho, M. C. GaRRAstazÚ, E. R. Nimmo, B. KellermanN, M. I. RADOMSKi, T. Beimgraben, P. P. Mattos and Y. M. M. Oliveira (2012): Sustainable Forest Management in Rural Southern Brazil: Exploring Participatory Forest Management Planning. In: DIEZ, J. J. (Ed.), Sustainable Forest Management - Case Studies. InTech.

Martinelli, G. and M. A. Moraes (2013): Livro vermelho da flora do Brasil. Instituto de Pesquisas Jardim Botânico do Rio de Janeiro, Rio de Janeiro.

MazzA, M. C. M. and J. V. M. Bittencourt (2000): Extração de DNA de tecido vegetal de Araucaria angustifolia (Araucariaceae). Boletim de Pesquisa Florestal, Colombo, 41: 12-17.

Sebbenn, A. M., A. C. M. Carvalho and M. L. M. Freitas et al. (2011): Low levels of realized seed and pollen gene flow and strong spatial genetic structure in a small, isolated and fragmented population of the tropical tree Copaifera langsdorffii Desf. Heredity 106: 134-145. doi:10.1038/hdy.2010.33

SoKAL, R. R. and F. J. RoHLF (1981): Biometry: The Principles and Practice of Statistics in Biological Research. Copyright Ltd., New York.

White, G. M., D. H. Boshier and W. Powell (1999): Genetic variation within a fragmented population of Swietenia humilis Zucc. Molecular Ecology 8, 1899-1909. 